\title{
WHAT QUALITIES DO GOVERNMENT-OWNED VENTURE CAPITAL INVESTORS SEEK IN A NEW VENTURE? - A COMPARISON OF INVESTMENT CRITERIA ACROSS PRE-SEED, SEED, AND EXPANSION STAGE STARTUPS
}

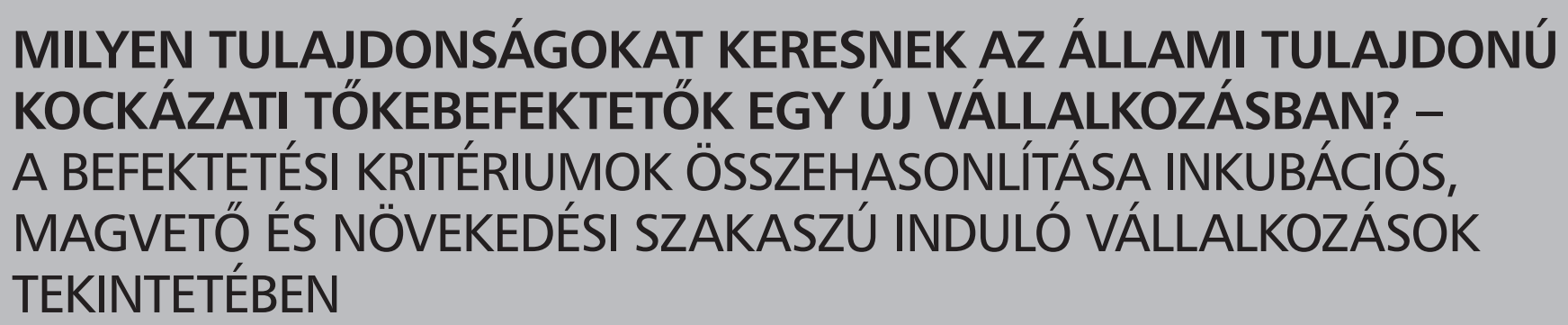

Private venture capital (VC) investors usually do not invest in early life-cycle stage startups such as seed and pre-seed companies, since investment size typically doesn't reach investment thresholds. The entry of governments with fund managers to venture capital markets presents seed and pre-seed companies with the opportunity to receive funding. This paper examines the main investment preferences of Hungarian government-owned venture capital investors regarding pre-seed, seed, and expansion stage startups. Verbal protocol analysis enabled examination of the screening process in real-time in all three life-cycle stages. It is found that governmental VC funds mostly value financial indicators followed by market-related qualities while private VCs value these characteristics in alternate formation. However, in the pre-seed stage, the financial acumen and capabilities of management teams form the main criteria in similarity to angel investors. Governmental VCs also greatly seek innovational value in target firms.

Keywords: venture capital, governmental venture capital, seed investment, investment criteria, startup financing, business plan

A magánpiaci kockázati tőkebefektetők jellemzően nem fektetnek be olyan korai fázisú induló vállalkozásokba, mint a magvető és inkubációs fázisú cégek, mivel a befektetési nagyság nem éri el a küszöbértéket. Az állam belépése a kockázati tőkepiacra a saját alapkezelőivel lehetőséget nyújtott magvető és inkubációs fázisú cégeknek a finanszírozású megszerzésére. Ez a cikk a magyar állami tulajdonú kockázatitőke-befektetők főbb befektetési preferenciáit elemzi az inkubáiós, magvető és növekedési fázisú induló vállalkozások tekintetében. A szerzők a verbal protocol elemzés segítségével képesek voltak valós időben adatokat gyűjteni a befektetések szűrési folyamatáról mindhárom fejlettségi életszakaszban. Azt találták, hogy az állami kockázati tőkés a pénzügyi és célpiaccal kapcsolatos tulajdonságokat értékeli a legtöbbre, pont fordítva a magánpiaci kockázati tőkésekhez képest. Az inkubációs szakaszban viszont a pénzügyi és menedzsmenttulajdonságok a legfontosabbak nekik, mint ahogy az üzleti angyaloknak is. Az állami kockázati tőkések továbbá nagy hangsúlyt fektetnek a céltársaságok innovációs értékére.

Kulcsszavak: kockázati tőke, állami kockázati tőke, magvető befektetés, befektetési kritérium, startup finanszírozású, üzleti terv

\section{Funding/Finanszírozás:}

The present publication is the outcome of the project „From Talent to Young Researcher project aimed at activities supporting the research career model in higher education”, identifier EFOP-3.6.3-VEKOP-16-2017-00007 co-supported by the European Union, Hungary and the European Social Fund.

\section{Authors/Szerzők:}

Endre Mihály Molnár, assistant research fellow, Corvinus University of Budapest, (molnar.endre@uni-corvinus.hu) Dr. Erika Jáki, associate professor, Corvinus University of Budapest, (erika.jaki@uni-corvinus.hu) 
Tnvestment preferences of venture capital investors have drawn substantial attention from researchers (for example, Tyebjee \& Bruno, 1984; Macmillan et al., 1987; Robinson, 1987; Khan, 1987; Sandberg \& Hofer, 1987; Hall \& Hofer, 1993; Zacharakis \& Meyer, 1995; Muzyka et al., 1996; Zacharakis \& Meyer, 1998; Shepherd, 1999; Mason \& Stark, 2004; Zacharakis \& Shepherd, 2005; Hsu et al., 2014). This interest was largely initiated by findings of Dorsey (1979), and Bruno and Tyebjee (1983), demonstrating that VCs are especially adept at choosing investments. Evolution of this research field followed a methodological path and dissection of the $\mathrm{VC}$ investment process with individual papers focusing on investment preferences in particular phases of the process. The literature in its current state tends to focus solely on the investment preferences of private VCs. This is not problematic in western economies where the majority of early-stage investments come from private actors. Currently however, such investments are primarily made by government-sponsored actors in the CEE (Central and Eastern Europe) region (Karsai, 2018; Jáki \& Molnár, 2017; Daszyńska-Żygadło et al., 2016, Jáki \& Molnár, 2021).

Governmental venture capitalists (GVCs) may have different preferences when choosing investments compared to private venture capitalists (PVCs). There are differences between actors concerning their investment approaches, including the target rate of return, motivation behind the investment, and ownership of managed funds. Currently, international literature lacks studies which investigate the investment preferences of GVC investors using reliable realtime methods and not just in regard to self-reporting by agents. Hence startup entrepreneurs in the CEE region typically need information on preferences of GVCs to become funded. This paper therefore aims to redress this balance.

In the CEE region, venture capital investment suffered setbacks following the 2008 financial crisis, but VC investments are currently increasing (see Figure 1). The structure of investment has also changed: the volume of seed investment increased from 4-5 million $€$ annually between 2007-2012 period to 38 million $€$ in 2018. The whole sector still has not re-attained the peak of 2008 in terms of investment volume but aided by EU venture capital programs, it is currently following a recovery trajectory.

Within the CEE region, Hungary presents a valuable setting to study this topic since venture capital investment volume was the highest in the region in 2018 (Invest Europe, 2019). Government policy in Hungary places significant emphasis on the development of the Hungarian startup ecosystem. This clear focus has been observed since the start of the Joint European Resources for Micro to Medium Enterprises (JEREMIE) program, which was a venture capital program financed by the European Union. Hungary participated in the program between 2009 and 2016, using obtained funds to stimulate the stagnant PVC market. PVC fund managers were selected to manage mostly state-provided sources in the framework of the program through hybrid funds and indirect involvement. In terms of investment volume the effort was successful as during the course of the program, venture capital investment increased dramatically in Hungary compared with previous years (see Figure 2).

Figure 1.

Venture capital investment volume in the CEE region between 2007 and 2018 in million EUR across different life-cycle stages

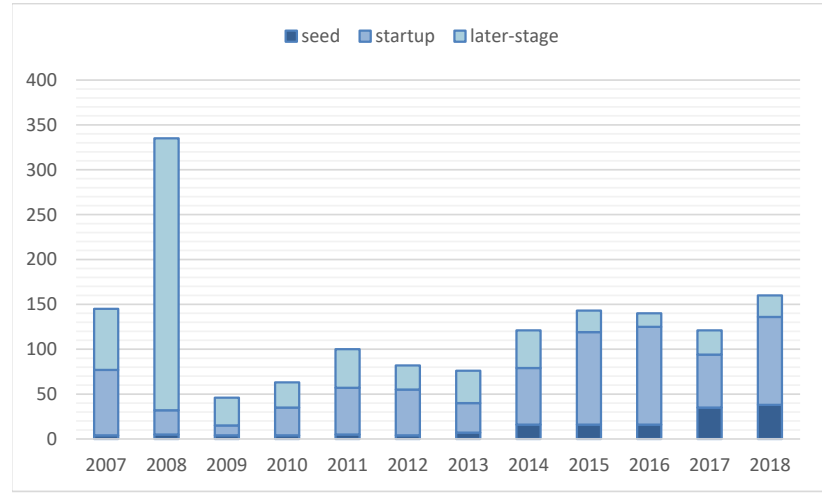

Source: Invest Europe (2019)

Figure 2.

Venture capital investment volume in Hungary between 2007 and 2018 in thousand EUR across different life-cycle stages

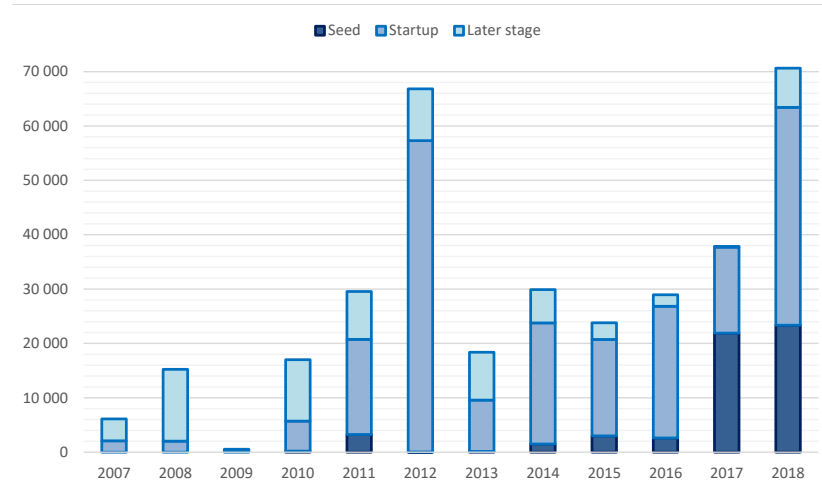

Source: Invest Europe (2017); Invest Europe (2019)

Other effects of the program are subject to debate in the literature (for example, Becsky-Nagy \& Fazekas, 2015; Jáki et al., 2017; Karsai, 2018; Lovas \& Illés, 2018; Berlinger, 2019; Kállay \& Jáki, 2019).

One aim of the JEREMIE program was that of regional development with participating fund managers intending to invest in peripheral regions of Hungary. However in reality they tended to invest in companies headquartered in a peripheral region, but with actual operations taking place in the capital city. Additionally, almost all of the fund managers acquired majority shares in the target companies which can reduce the long-term motivation of founding members (Lovas \& Illés, 2018). When analyzing data of firms receiving investment from JEREMIE funds, Fazekas and Becsky-Nagy (2019) found a negative relationship between firm growth and the equity share of VC in the firm. Furthermore, Fazekas (2018) found that 
companies receiving funding directly from GVC funds performed better than those which received funding from JEREMIE sources thus indicating that private investor's motivation does not necessarily lead to improved company performance. In a later article (Fazekas \& Becsky-Nagy, 2020), it is concluded that generally moral hazard may lead to poorer results of hybrid GVC-PVC investments compared to pure GVC investments.

Karsai (2017) suggested there is a range of best practices which governments of developed countries already learnt and acquired through the evolution of governmental VC programs, and that such best practices should be implemented in future domestic VC programs by CEE countries. Primarily, the duration of the program should be sufficiently short to influence the market as little as possible, bureaucratic requirements should be minimized, and data should be collected during the program to perform a final complete evaluation.

From 2016 the government continued to support development of the startup ecosystem by shifting focus away from hybrid funds and by directly investing state resources through state-owned fund managers as direct involvement. In initial stages of seeking startup financing (namely seed and pre-seed capital), companies can usually not depend on PVC financing, since investment sums are so small it is not economical for PVC providers to commit to funding. However, GVC fund managers tend to offer possibilities for very early-stage companies to receive initially small investments with the possibility of a follow-up round. Additionally, GVC investors can only acquire minority shares in target companies, which helps founders to be motivated in the longer term. In this regard, GVC can be regarded as complementary to PVC in Hungary. As can be observed in Figure 1, the overall investment volume started to increase again in 2017, and in 2018 reached its highest point in the decade which is in large part due to direct investment. Moreover, alternative sources of early-stage investments are also becoming more widespread, including investment from angel investors, incubators, accelerators, crowdfunding, or seed funds connected to corporations and universities (Karsai, 2019).

Startup companies face problems when applying for GVC financing in the earlier life-cycle stages such as preseed and seed investment. The literature tends to only deal with the preferences of traditional PVC investors which tend not to invest in early stage startup companies due to prominent market failures such as information asymmetries and transaction costs (Colombo et al., 2016; Lovas, 2015), hence there is a lack of VC investment preference research in such early phases. The question therefore arises as to how startup firms can predict investment preferences of VC investors in early-stage investments by studying literature on angel investment preferences. In general, this is not possible as the literature tends to indicate fundamental differences in the selection criteria of angel and VC investors due to different professional backgrounds, portfolio size, and approaches to dealing with risk (Hsu et al., 2014; Mason \& Stark,
2004). This paper further aims to also solve this problem in order to assist startup companies in receiving a better understanding of qualities GVC investors seek in ventures in various life-cycle stages.

\section{Literature Review of Investment Preferences studies}

Investment preferences of venture capital investors have been examined by researchers from the early 1980s, originating in the USA by use of a variety of methods. With ongoing evolution in research methodology, the earliest papers mainly used questionnaire and interview instruments to find out more about how VCs select target companies.

Tyebjee and Bruno (1984) used structured interviews and questionnaires to identify five common factors behind VC investment decisions as follows: (1) Market Attractiveness, (2) Product Differentiation, (3) Managerial Capabilities, (4) Environmental Threat Resistance. This work laid the foundation for further studies by acting as a vanguard in discovering the main influential factors. Macmillan et al. (1987) aimed to validate results with a larger sample of VCs and found that the most important investment factor was in the consistent capabilities of management, as in "irrespective of the horse (product), horse race (market), or odds (financial criteria) it is the jockey (entrepreneur) who fundamentally determines whether the venture capitalist will place a bet at all" (Macmillan et al., 1987, p. 10). This observation is corroborated by Robinson (1987) who suggests that management teams need to be complete and must have acquired business skills through experience. Robinson (1987) also emphasizes the importance of the balance between technical skills needed for the production or provision of the service, entrepreneurial experience of key players, and requirements of the specific market. Khan (1987) used a decision-making model to estimate the impact of VC decisions on realized returns and found that creativity and resourcefulness of the entrepreneur in addition to the ability to enter new markets innovatively is the most significant determinant of realized profits on the investment. Dávid and Becsky-Nagy (2016) conducted a questionnaire to assess investment preferences of Hungarian VC providers who mostly indicated they prefer the capability of an investment to generate a return over any other given characteristic of an investment opportunity.

All the previously mentioned papers used questionnaires and interviews as the main data collection method. However, Sandberg and Hofer (1987) warned against the use of questionnaires in studies on VC investment preferences in that it was felt the decisionmaking process might be falsely simplified by such means. It was further suggested researchers use real-time methods, such as observation and verbal protocol as data gathering techniques to study this field. Subsequently, Zacharakis and Meyer (1998) indicated that methods such as questionnaires and interviews used in earlier works are most likely biased due to individuals being prone to 
remember their experiences and preferences in a distorted manner through recall bias. Furthermore, respondents may try to justify their previous actions after the event in post hoc rationalization. Hence it may be extremely difficult for $\mathrm{VC}$ fund managers to become introspective about their own decision-making processes.

This gave rise to the use of verbal protocols as a real-time method based on observing VCs during the investment assessment process. Hall and Hofer (1993) conducted 16 verbal protocols with VCs by observing and recording how they evaluated startup investment proposals. They found that VCs tended to only read documents until they discovered a critical fault, thus resulting in immediate rejection. They also concluded that in the pre-screening phase VCs most valued the quality of the proposal and investor fit. In second-round funding assessments however VCs most valued startups recommendations from partners. Zacharakis and Meyer (1995) also used the verbal protocol analysis approach by involving two VC firms which had to partly evaluate their prior investment proposals, and partly evaluate those provided by researchers. It was found that VCs most valued innovative qualities of the startup's products or services. The study also concluded these must be introduced as early as possible in the business plan. Mason and Stark (2004) however not only studied VC investment preferences, but compared the investment preferences of business angels, bankers, and VCs using verbal protocol analysis. The study found that VCs mostly valued market growth potential, market demand, the presence of entry barriers, and the financial indicators of startups such as financial ratios, company value, and expected return on exit. However, quality of the management team was not found to be of much importance for VCs to thereby contradict the findings of the questionnaire-based studies of the 1980s. Analysis in this present paper builds on the preference comparison approach used by Mason and Stark (2004). There have also been other applications of verbal protocol analysis in the study of investment decision making processes in the early stage angel investor segment (for example, Smith et al., 2010; Harrison et al., 2015; Mason \& Botelho, 2016).

Apart from verbal protocol analysis, a research method which became favored by VC investment decision researchers is that of conjoint analysis. This involves researchers posing a series of investment decision-pair choices to VCs which differ in terms of various pre-defined qualities, and tVCs are asked to select between them. Results are statistically analyzed to detect the main factors behind investment decisions. This method also provides a solution to the recall bias and post hoc rationalization problems, but gathered data tends to be less information-rich than data collected by verbal protocol analysis. Muzyka et al. (1996) conducted a conjoint analysis study using data collected from European VC managers who had to choose between 53 paired investment opportunities. They found leadership capabilities, experience, sales skills of the management team and sustainability of market share to be the most sought-after qualities by VCs. Shepherd (1999) also used conjoint analysis on data collected from Australian VC managers and found the industry experience and education of the management team and the strength of the competitors to be the most relevant factors. In their conjoint analysis study, Zacharakis and Shepherd (2005) found the same factors to be strong in addition to product differentiation and market growth potential. Finally, by use of conjoint analysis Hsu et al. (2014) found that angel investors place more emphasis on strategic readiness and affective passion than VC managers who prefer economic potential.

\section{Research goals}

This study examines the investment preferences of GVC investors in general and particularly in pre-seed, seed, and expansion stage investment phases using the real-time research method of verbal protocol analysis. It therefore provides a much-needed extension to the current literature on $\mathrm{VC}$ investment preferences by aiming to answer the following research question: what qualities do GVC investors value in target companies in various life-cycle stages?

It is intended to explore the qualities GVC investors will value overall and it is expected that GVC investors tend to mimic investment preferences of PVC investors. Based on the literature, this leads to an expectation for GVC investors to value market characteristics the most, followed by that of financial indicators (Zacharakis \& Shepherd, 2005; Mason \& Stark, 2004; Shepherd, 1999).

\section{H1a: Overall, GVC investors value the market the most followed by financial indicators of target com- panies.}

Additionally, by using EU funds the Hungarian government launched the GINOP program as part of the 2014-2020 programming period with the explicit aim of developing the innovational capabilities of the economy (Palyazat.gov.hu, 2014). Many of the subprograms include investment into GVC funds, leading to an assumption that in overall terms GVC investors highly value the innovational quality of the product or service of a target company.

\section{H1b: Overall GVC investors value the innovational value of the product highly within the product/ser- vice category.}

It is also expected to observe variations in the results of the three investment phases. In the pre-seed phase a suitable indicator of the GVC investor's preferences may be that of criteria used by angel investors, who tend to invest in the earliest life-cycle stages of startup companies. Angel investors are highly influenced by the personal qualities of entrepreneurs in their investment decisions because the problem of information asymmetries is very prevalent in the pre-seed phase (Hsu et al., 2014). It is expected that 
management teams form the most important consideration in the early investment stages, given literature suggests that in these stages investors mainly base their decisions on the quality of management. This may be due to relatively little information available on the history of companies, thus it is generally hard to rely on financial data or projections (Hsu et al., 2014). Additionally, business plans formed in these stages are not necessarily very precise, since the product or service of the company is typically not finalized, leading to investors not placing strong emphasis on the quality of the business plan. Thus a hypothesis is formed that if the GVC faces similar problems in the pre-seed investment phase as angel investors, then it will follow a similar preference structure by placing the highest importance on management of the target company and less importance on the business plan and financial indicators.

\section{H2a: In the pre-seed phase, the management of the target company is among the most valued charac- teristics by the GVC investor. \\ H2b.: In the pre-seed phase, the financial indicators of the company are among the least valued charac- teristics by the GVC investor. \\ H2c: In the pre-seed phase, the business plan of the company is among the least valued characteristics by the GVC investor.}

Traditional VC investors tend not to invest in pre-seed companies due to the high transaction cost of investing and the lack of economies of scale in small investments. Thus they tend to prefer more developed startups which require larger investments. Thus in the seed and expansion stages, it is expected for GVC investors to invest according to the preference of PVC investors. There may however be a slight difference in that while PVC investors tend not to highly value the quality of business plans (Zacharakis \& Shepherd, 2005; Mason \& Stark, 2004; Shepherd, 1999), it is expected GVC investors may value them to a stronger degree. Furthermore, it is known that VCs connected to the government are subject to increased levels of bureaucracy (Karsai, 2017), an aspect which could be manifested in increased attention to the business plan structure as the basis for further record-keeping.

\begin{abstract}
H3a: In the seed phase, the GVC investor values the market the most followed by the financial indicators of the target company.

H3b: In the seed phase, the GVC investor values the business plan of the target company among the top three characteristics.

H4a: In the expansion phase, the GVC investor values the market the most followed by the financial indicators of the target company.

H4b: In the expansion phase, the GVC investor values the business plan of the target company among the top three characteristics.
\end{abstract}

Differences between GVC and PVC investors in terms of industry focus, the goal of the investment, and regulation of the investment selection process may influence the final result. The implications of this study should help startups in assessing their readiness to approach GVC investors according to the current life-cycle stage of ventures and should also enable policy-makers to receive experiencebased feedback on the realization of governmental investments.

\section{Methodology}

In this chapter, the sample base, data collection and analysis techniques are discussed.

\section{Sample}

The sample was collected in spring 2018 and consisted of three Hungarian GVC investment managers investing in pre-seed startups, three investing in seed startups, and three investing in expansion-stage startups, totaling nine GVC investment managers. They were identified with the help of an inside expert through expert sampling who was asked to suggest managers from each life-cycle specialization stage for the best representation in terms of demographic characteristics (Horváth \& Mitev, 2015). A random sample would have been ideal for purposes of this study, however due to lack of information on the GVC sector it is generally not possible. Reputation-based sampling is widely regarded as the second-best option for generalizability. The investment managers were male, middle-aged and in possession of a business or finance master's degree. All were required to be proficient with business plans and company valuation. Based on interviews with other venture capital managers these demographic characteristics can be also generally observed at PVC firms, hence they are unlikely to be the source of different outcomes.

Pre-seed GVC investors tend to target startups with little information and provide a modest amount of investment. Seed GVC investors target startups that already started developing a prototype and gathering market feedback, thus generally providing higher investment levels. Expansionstage GVC investors tend to target established startups, which have already completed prototype development and have sufficient market feedback to provide a substantial amount of investment. One aim of this study is to indicate how GVC investment preferences differ between the three types of GVC investors and across the different life-cycle stages.

Each verbal protocol interview took place over one hour during which two verbal protocol exercises were successfully completed. This resulted in 18 verbal protocol transcripts to work with. Very rich data is generated through this method but it is exceptionally time-consuming, thus the typical sample size for these studies is small. For comparison, Hall and Hofer (1993) conducted 16 verbal protocol interviews, Zacharakis and Meyer (1995) conducted 4 such interviews and Mason and Stark (2004) conducted 9 interviews with VCs. Additionally, Chiu and Shu (2010) found that the typical 
sample size of verbal protocols for problem-solving studies is between 1 and 20 which also confirms that the sample size in this study is at the higher end for this type of methodology. Finally given that data captured in realtime from GVC investors is especially hard to obtain, the sample in this study contains important information on GVC investors.

\section{Data collection procedure}

Verbal protocol analysis consists of real-time observation during which researchers record the subject's thinking and decision-making processes. During the phase of observation and recording, investment managers read a business plan sent by startup entrepreneurs while articulating their critical thoughts and impressions. The procedure for conducting a verbal protocol is formed of the following stages outlined by Ericsson and Simon (1993):

1. Before the start of the experiment, it should be made clear to subjects that they must continuously articulate their thoughts explicitly during the experiment, including anything that comes to mind. If the subjects are silent for more than 30 seconds, the researcher must remind them to continue articulating their thoughts.

2. Before the start of the experiment, it is advised to conduct a test run by for example solving an easy mathematical problem. The researcher can ask the subject to perform a simple arithmetic addition task but to express every emerging thought clearly while performing the task. Hence the subject can receive some experience of the method before the start of the experiment.

3. Perform the verbal protocol experiment and audio record the narrative.

4. Transcribe the recordings to commence the analysis.

This authorship team strived to follow closely these principles. Special consideration was made in regard to business plans evaluated by the investment managers. Providing each participant with the same business plans poses various problems. For example, if an investment manager reads the business plan of a startup that doesn't fit his or her industry and life-cycle specialization, then the investment proposal will most probably be rejected outright. Another problem is that business plans provided by the researchers tend to decrease the practical validity of the research. However, if VCs are asked to read and evaluate business plans they themselves received, then these problems generally do not emerge, and the validity of the study is greatly enhanced (Zacharakis \& Meyer, 1995). While being aware that giving the investors the same business plans would have increased the comparability of results, the benefits of evaluating actually received real business plans far outweigh the costs (Zacharakis \& Meyer, 1995). Verbal protocol analysis is an adept tool for examining decision scenarios, provided that the following criteria are met as drawn from Ericsson and Simon (1993) and which took place in this study as outlined in Table 1.

Table 1.

\section{The implementation of verbal protocol analysis criteria}

\begin{tabular}{|l|l|}
\hline \multicolumn{1}{|c|}{ Criteria } & \multicolumn{1}{|c|}{ Implementation in our research } \\
\hline $\begin{array}{l}\text { The information report- } \\
\text { ed must be the focus of } \\
\text { attention }\end{array}$ & $\begin{array}{l}\text { Each interview was made in an un- } \\
\text { disturbed, silent, closed office room } \\
\text { with only the interview subjects and } \\
\text { researchers present. }\end{array}$ \\
\cline { 1 - 1 } $\begin{array}{l}\text { Subjects are free from } \\
\text { distraction }\end{array}$ & $\begin{array}{l}\text { Real business plans from various } \\
\text { industries were used. }\end{array}$ \\
\hline $\begin{array}{l}\text { The task is not highly } \\
\text { routinized by habit }\end{array}$ & $\begin{array}{l}\text { Subjects continuously articulated } \\
\text { their thoughts out loud during eva- } \\
\text { luation of the business plan and } \\
\text { were reminded to continue articula- } \\
\text { ting their thoughts after being silent } \\
\text { for 30 seconds. }\end{array}$ \\
\cline { 1 - 1 } $\begin{array}{l}\text { There must be only short time between } \\
\text { performance and verbal } \\
\text { ization }\end{array}$ & $\begin{array}{l}\text { The subjects articulated their own } \\
\text { thoughts as they came to mind. }\end{array}$ \\
\cline { 1 - 2 } $\begin{array}{l}\text { Verbalization does not } \\
\text { require excessive en- } \\
\text { coding }\end{array}$ & $\begin{array}{l}\text { Oral interviews were conducted } \\
\text { personally } \\
\text { Reports are oral } \\
\text { clear explanations were given on the } \\
\text { method and the aim of the study. }\end{array}$ \\
\hline $\begin{array}{l}\text { Completeness in report- } \\
\text { ing is encouraged }\end{array}$ & $\begin{array}{l}\text { Each business plan evaluation was } \\
\text { completed }\end{array}$ \\
\hline
\end{tabular}

Source: own editing

\section{Data analysis procedure}

Firstly, the verbal protocol recordings were transcribed. In the transcribed text the so-called 'thought segments' were identified, which may be words, partial sentences, or complete sentences representing a coherent and distinct thought unit. To arrive at measurable results, each thought segment should be coded into a qualitative property or category, the importance of which was needed to measure investment decisions. Following rationale set out in previous studies (Hall \& Hofer, 1993; Mason \& Stark, 2004; Robinson, 1987; Zacharakis \& Meyer, 1995, 1998), categories were drawn to answer the research question (see Table 2). The financial category mainly contains comments on the financial section of the business plan consisting of the planned revenue and cost structure, capital expenditures, and cash-flows. This financial plan is required in all three life-cycle stages. Additionally, it contains insights on the investment manager's view of exit possibilities in for example prospective buyers of a company and its possible value given that based on mental calculations company valuations are not required in such financial plans. Deductive coding was used meaning whereby the range of qualitative indicators used as categories can be increased with the discovery of thought segments which do not fit into predefined categories (Cho \& Lee, 2014). 
Qualitative properties used as categories

\begin{tabular}{|l|l|}
\hline Management & $\begin{array}{l}\text { previous entrepreneurial experience of the } \\
\text { management team } \\
\text { education level of the management team } \\
\text { presence of core competencies }\end{array}$ \\
\hline $\begin{array}{l}\text { Product / Ser- } \\
\text { vice }\end{array}$ & $\begin{array}{l}\text { innovational value of the product or service } \\
\text { readiness level of the product or service } \\
\text { appearance of the product or service }\end{array}$ \\
\hline Market & $\begin{array}{l}\text { growth potential, scalability } \\
\text { saturation of the market, entry barriers }\end{array}$ \\
\hline Business plan & $\begin{array}{l}\text { depth of the business plan } \\
\text { level of professionalism of the business plan }\end{array}$ \\
\hline Financials & $\begin{array}{l}\text { financial plan (revenue and cost structure, } \\
\text { capital expenditures, cash-flows) } \\
\text { company value } \\
\text { exit-opportunities }\end{array}$ \\
\hline $\begin{array}{l}\text { Positive exter- } \\
\text { nalities }\end{array}$ & $\begin{array}{l}\text { job creation } \\
\text { regional development } \\
\text { sustainability } \\
\text { positive social impact }\end{array}$ \\
\hline
\end{tabular}

Source: own editing

Each thought segment was successfully linked to one of the categories defined above. On this basis, frequency tables for results were created for each type of GVC investor (pre-seed, seed, and expansion) to identify differences between the most relevant qualities of a startup's business plan across the different life-cycle stages. The use of frequency tables is standard practice when conducting verbal protocol analysis and it is present in numerous studies examining investment preferences (for example, Hall \& Hofer, 1993; Mason \& Stark, 2004; Smith et al., 2010).

As with all other research methods, verbal protocol analysis has limitations. These include the possibility of frequency counts of thought units not completely representing the importance of the preference criteria because the participant may mention a particular point multiple times due to not being certain while he/she may only mention another point once when he/she is absolutely certain. Additionally, even though it is a real-time datacollection method tool the experiment-like nature of verbal protocol interviews might also distort the behavior of the subject (Mason \& Stark, 2004).

\section{Results}

The frequency of qualities assessed by the GVCs in general and across the three types of investors is very revealing. Each GVC investor type (pre-seed, seed, and expansion) evaluated six different startup business plans and their thought segments were linked to six categories: financial indicators, market, product and service, management team, business plan, and positive externalities. In Table 3 frequencies of thought segments in each category in total and per life-cycle stage can be observed.
Frequency table of investment preferences based on verbal protocol analysis

\begin{tabular}{|l|c|c|c|c|}
\hline \multicolumn{1}{|c|}{ Category } & \multicolumn{4}{|c|}{ Frequency (\%) across the life-cycle stages } \\
\hline & Pre-seed & Seed & Expansion & Total \\
\hline $\begin{array}{l}\text { Financial } \\
\text { indicators }\end{array}$ & $25,4 \%$ & $31,8 \%$ & $27,5 \%$ & $\mathbf{2 8 , 4 \%}$ \\
\hline Market & $21,9 \%$ & $25,8 \%$ & $21,4 \%$ & $\mathbf{2 3 , 3 \%}$ \\
\hline $\begin{array}{l}\text { Product and } \\
\text { service }\end{array}$ & $21,9 \%$ & $23,7 \%$ & $21,4 \%$ & $\mathbf{2 2 , 5 \%}$ \\
\hline $\begin{array}{l}\text { Management } \\
\text { team }\end{array}$ & $23,7 \%$ & $13,0 \%$ & $15,4 \%$ & $\mathbf{1 7 , 5 \%}$ \\
\hline Business plan & $7,1 \%$ & $5,7 \%$ & $14,3 \%$ & $\mathbf{8 , 2 \%}$ \\
\hline
\end{tabular}

Source: own database

Figure 3.

\section{Overall investment preference hierarchy based on} verbal protocol analysis

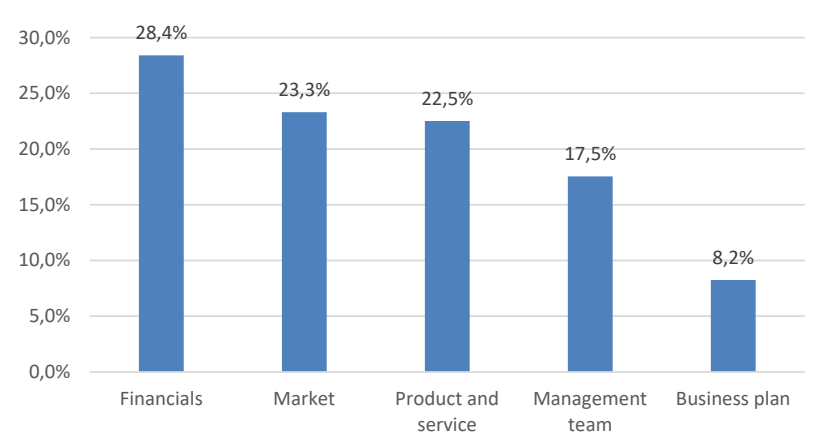

Source: own database

Overall examination of results reveals that GVC investors valued financial indicators of the company most highly $(28,4 \%)$, followed by the market $(23,3 \%)$. This is completely opposite to preferences of PVC investors, who generally mostly value the market followed by financial indicatorss (Zacharakis \& Shepherd, 2005; Mason \& Stark, 2004; Shepherd, 1999). This result does not support hypothesis H1a stating that GVC investors mostly overall value the market followed by the financial indicators of the target company. The reason behind this can be in very strict state oversight which GVCs operate under, thereby requiring them to closely follow financial guidelines when selecting target companies. The market and product/service are almost equally important in the evaluation process. The high ranking of the product/service category is interesting because there is evidence in the literature that VCs do not value this factor highly. For example, Mason and Stark (2004) found it to be one of the least valued characteristics. A possible reason behind this coalesces with hypothesis H1b: "Overall GVC investors value the innovational value of the product highly within the product/service category". It emerged that the contribution of observations on the innovational value of the product form a large portion of the total observations on the product, as seen in the Figure 4. 
Figure 4.

Share of innovation-related observations within the product and service category based on verbal protocol analysis

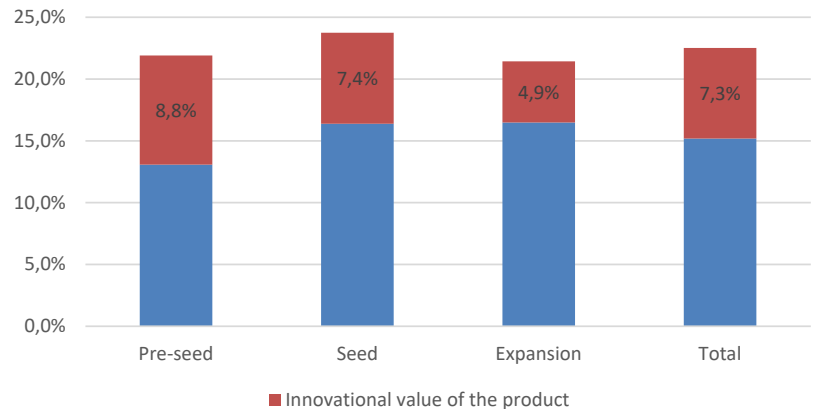

Source: own database

It is also notable that the GVCs discuss the innovational value of the product relative to all product-related observations mostly in the pre-seed phase (40\% share), and less in the later phases (seed: $31 \%$ share, expansion: $23 \%$ share). This may be due to less market validation information available about the company in the earliest phases which places more responsibility on the VC to determine if there are innovational properties in the product or not. Innovation is already market-tested in expansion stage companies, thus there is less need for analysis. Overall, this outcome supports hypothesis H1b. Combining the two findings that (1) the GVC places a large emphasis on the quality of the product/service and (2) within the product/service category, analysis of the innovational value makes up a large portion. It is therefore found that the GVC investor values the innovational value of the product most highly.

In terms of overall ranking, quality of the business plan $(8,2 \%)$ attains the lowest level of importance. Thus, startup entrepreneurs seeking state investment should be aware that their companies should have very good financial prospects to receive funding. In the following sections, the results of the three investment phases are analyzed, where some variation may arise.

\section{Pre-seed}

To identify qualities sought by GVC investors in pre-seed ventures results of pre-seed GVC verbal protocols are examined. Surprisingly, the most discussed criterion of the pre-seed GVC investors was again found in financial characteristics of the company $(25,4 \%)$, closely followed by the management team $(23,7 \%)$. However, management was the most discussed factor by pre-seed GVC investors when compared with others (seed: $13 \%$, expansion: $15,4 \%$ ) (Figure 5.).

Hypothesis 2a proposes that in the pre-seed phase GVCs mostly value qualities of the management team, similarly to angel investors. This hypothesis is partly supported since the management team formed the highest valued characteristic compared to other investment phases, but it was not the most absolutely highest category valued in the pre-seed phase. The issue of planned equity shares of key players is also relevant in the life-cycle stage. The importance of the financial indicators suggests that GVCs place strong emphasis on profitability and return potential of a startup even in infancy stage. Within this category, GVCs gave special attention to the composition of the equity holders. The GVCs placed equal emphasis on the market and the product consideration $(21,9 \%$ in both cases). These are still relatively high weights, and several business plans were criticized for lack of diligent market analysis, especially regarding the identification of competitors. In some cases, the gathering of market feedback was strongly appreciated. In terms of the product, GVCs seemed to focus most on the innovational value, as in "we are looking for something that hasn't been done a million times before". Innovativeness was also shown to be a key driver of entrepreneurial growth by Czyżewska et al. (2016).

Figure 5.

\section{Pre-seed stage and overall investment preference hierarchy based on verbal protocol analysis}

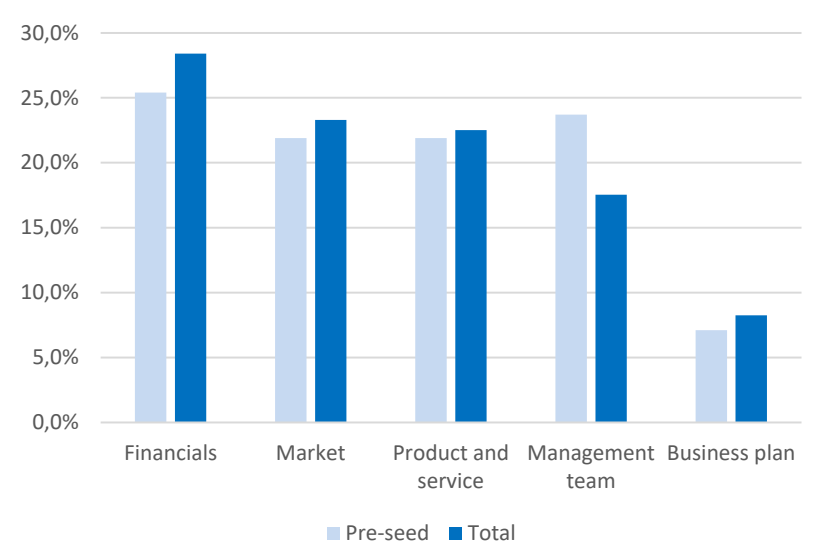

Source: own database

Evidence of pre-seed GVC investment managers operating according to an entirely different preference structure than PVC investors was also noted. Financial indicators of the company are seen as the most important quality in a startup application for funding followed closely by that of the management team. The importance of the management team in this phase resembles the investment preference of angel investors (Hsu et al., 2014; Mason \& Stark, 2004). This is most likely because in the pre-seed phase where angel investors are also active, investors should base their decision on the perceived capabilities of the management, as in this very early phase there is little verifiable information available about a given project thus leading to informational asymmetry. This renders the importance GVCs place on the financial indicators of the company in the pre-seed phase as even more surprising, thus hypothesis $\mathrm{H} 2 \mathrm{~b}$ "In the pre-seed phase, the financial indicators of the company are among the least valued characteristics by the GVC investor" is not supported. Hence the prior explanation that GVC investors spend the resources of the state is strengthened in that their accountability is elevated and their investment decision 
is supported by the estimated financial indicators of the business plans. This finding is common to all three lifecycle stages.

The qualities attached to the structure and flow of the business plan were under minimal scrutiny in the preseed category $(7,1 \%)$, thus strong support for hypothesis $\mathrm{h} 2 \mathrm{c}$ proposing that in the pre-seed phase the quality of the business plan is one of the least valued characteristics was evident. This is understandable since at this early stage, the length of the required plan tends to be much shorter than in later stages.

\section{Seed}

Qualities sought in seed ventures by GVC investors are examined in this section. The most scrutinized factor is once again clearly that of the financial indicators $(31,8 \%)$. The financial plan, especially in terms of the price and cost structure is the subject of most criticism (Figure 6.).

Figure 6.

Seed stage and overall investment preference hierarchy based on verbal protocol analysis

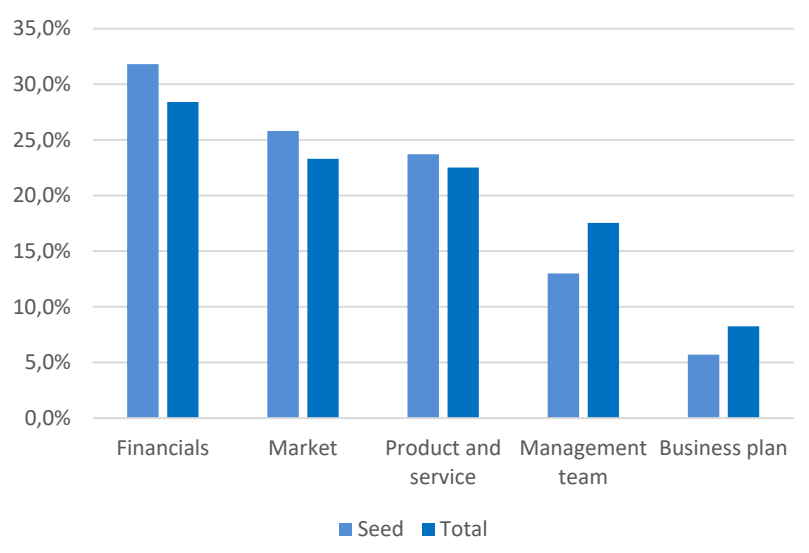

Source: own database

Since financial criteria of the seed stage startup phase tend to be more valuable than in the pre-seed stage it is understandable that a detailed financial plan for the near future becomes a more significant criterion. However, it is still very hard to forecast because of a lack of substantial historical data. The other two main factors in the seed investments consisted of the market $(25,8 \%)$ and the product $(23,7 \%)$ with the management team $(13 \%)$ and business plan $(5,9 \%)$ forming the least important categories. It was very interesting to note the management team factor achieving such low importance in the seed stage. This resembles findings of prior verbal protocol studies (for example Hall \& Hofer, 1993; Zacharakis \& Meyer, 1995; Mason \& Stark, 2004) on VC investment preference indicators given it is also suggested to be in stark contrast to previous post-hoc studies by Tyebjee and Bruno (1984), Macmillan et al., (1987), Robinson (1987) and Khan (1987). However, hypothesis 3a, proposing that GVC investors mostly value the market followed by financial indicators in the seed stage can not be supported. This hypothesis was formed by assuming GVCs follow the investment preference structure of PVCs in the seed and expansion stage but also place a higher emphasis on the business plan than PVC investors. In contrast, results in this study indicate that GVCs value financial indicators the most, followed by the market which further confirms high regard given to financial indicators by GVCs, suggesting the need to follow a strict financial evaluation process in selecting target companies, in order to comply with state regulations. Quality of the business plan was the least valued characteristic (5,9\%), therefore hypothesis $\mathrm{H} 3 \mathrm{~b}$ proposing that the business plan is in the top three characteristics in the seed phase can not be supported. This essentially implies that GVCs are free to place more emphasis on the factors that are important in regard to the business and there is little need to scrutinize the business plan structure, which is also very consistent with the manners in which PVCs tend to value this characteristic. Hence it can be concluded that the state-controlled nature of GVCs materializes in their focus on the financial prospects of the business plan and not upon the structure and general quality of the business plan. This is another finding that startup entrepreneurs might bear in mind when applying for GVC financing.

\section{Expansion}

Figure 7.

Expansion stage and overall investment preference hierarchy based on verbal protocol analysis

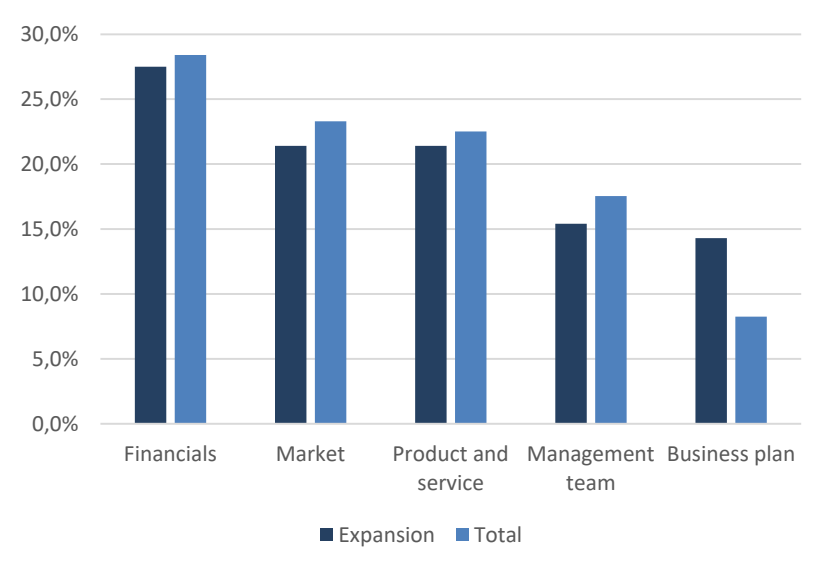

Source: own database

Qualities GVC investors seek in expansion-stage ventures are examined forthwith. Results of expansion stage evaluations resemble those of the seed stage in the sense that the financial indicators of the company are deemed the most important $(27,5 \%)$, followed by the market $(21,4 \%)$. However in this case the product or service holds the same importance as the market $(21,4 \%)$ (Figure 7.$)$.

Similarly to previous results, this finding does not support hypothesis $4 \mathrm{a}$, proposing that GVC investors mostly value the market followed by the financial indicators of the target company in the expansion stage. However, construction of the business plan $(14,3 \%)$ has much higher importance in this phase compared to other phases which can be attributed to the business plans being the longest 
at this life-cycle stage. Hence there is more opportunity to criticize their structure and flow, but hypothesis $\mathrm{H} 4 \mathrm{~b}$ is not supported since the business plan is not in the top three most valued characteristics. Thus, entrepreneurs applying for expansion stage GVC financing should devote more resources to competent construction of the business plan compared to the earlier stages. However they still can expect to receive relatively little criticism related to the quality of the business plan. The Table 4 . contains results associated with the hypotheses. tendencies of the market, the market share and pricing power of market participants, and the plan to capture a targeted share of the market. The business plan should follow a coherent structure and style and should be as concise, factual and straightforward as possible and preferably present data through graphical means. Use of 'buzzwords' should be avoided. Ideally, the plan should follow the structure laid out in the executive summary. Additionally, pre-seed startup plans should also contain references to support their major propositions.

Table 4.

Result table for hypotheses

\begin{tabular}{|c|c|c|c|c|}
\hline & Hypothesis & Supported & Partly supported & \begin{tabular}{|l|} 
Not supported \\
\end{tabular} \\
\hline & $\begin{array}{l}\text { Overall, GVC investors value the market the most followed by } \\
\text { financial indicators of target companies. }\end{array}$ & & & $\mathrm{X}$ \\
\hline $\mathrm{H} 1 \mathrm{~b}$ & $\begin{array}{l}\text { Overall GVC investors value the innovational value of the product } \\
\text { highly within the product/service category. }\end{array}$ & $\mathrm{X}$ & & \\
\hline $\mathrm{H} 2 \mathrm{a}$ & $\begin{array}{l}\text { In the pre-seed phase, the management of the target company is } \\
\text { among the most valued characteristics by the GVC investor. }\end{array}$ & & $\mathrm{X}$ & \\
\hline $\mathrm{H} 2 \mathrm{~b}$ & $\begin{array}{l}\text { In the pre-seed phase, the financial indicators of the company are } \\
\text { among the least valued characteristics by the GVC investor. }\end{array}$ & & & $\mathrm{X}$ \\
\hline $\mathrm{H} 2 \mathrm{c}$ & $\begin{array}{l}\text { In the pre-seed phase, the business plan of the company is among the } \\
\text { least valued characteristics by the GVC investor. }\end{array}$ & $\mathrm{X}$ & & \\
\hline H3a & $\begin{array}{l}\text { In the seed phase, the GVC investor values the market the most } \\
\text { followed by the financial indicators of the target company. }\end{array}$ & & & $\mathrm{X}$ \\
\hline $\mathrm{H} 3 \mathrm{~b}$ & $\begin{array}{l}\text { In the seed phase, the GVC investor values the business plan of the } \\
\text { target company among the top three characteristics. }\end{array}$ & & & $\mathrm{X}$ \\
\hline $\mathrm{H} 4 \mathrm{a}$ & $\begin{array}{l}\text { In the expansion phase, the GVC investor values the market the most } \\
\text { followed by the financial indicators of the target company. }\end{array}$ & & & $\mathrm{X}$ \\
\hline $\mathrm{H} 4 \mathrm{~b}$ & $\begin{array}{l}\text { In the expansion phase, the GVC investor values the business plan of } \\
\text { the target company among the top three characteristics. }\end{array}$ & & & $\mathrm{X}$ \\
\hline
\end{tabular}

Source: own database

Demonstration of the main criticisms of investment managers on the product, market, management team, financial indicators, and business plan structure of startup companies and formulation of advice on how to better write a business plan is another significant contribution of this paper. Based on observations of investment managers, it is advised that introduction to the product or service should begin with identification of the main market based problem to be addressed for which the product or service proposes a solution. Entrepreneurs should also double-check to ensure their product does hold innovational value, or merely imitates that of competitors. Finally by entrepreneurs only revealing positive aspects of their products or services investment managers can be significantly deterred. Hence attention to the shortcomings of products or services is essential.

The business plan should indicate that there is market demand for the product or service of the startup company verified by market data and by user feedback. This aspect is generally required even in pre-seed business plans but is greatly emphasized in the seed and expansion stages. In the latter two stages, additional information is required for the market study which should be mostly based on publicly available data related to the size and
The management team should contain essential core competencies required for the success of a startup company. Furthermore, team members in possession of core competencies should be significant shareholders of the firm. The aim should be to avoid larger competitors luring away key employees to notionally guarantee that key players of a startup company will support the success of the business in the long run. For this reason, founders should carefully consider the distribution of equity between key management team members. Furthermore, startup management teams should show "great passion and enthusiasm" for their project and should be able to dedicate the majority of their time to it.

The most important financial requirement is that of 'scalability'. If a startup company is not scalable, then the $\mathrm{VC}$ is typically unable to make a subsequent profitable exit because growth of the business is limited. For this reason, it is generally much harder for companies with a physical product to convince the $\mathrm{VC}$ to invest, while technological startups tend to be favored for $\mathrm{VC}$ financing. However, even technological startups tend not to receive $\mathrm{VC}$ financing if for example advertising revenues are their sole form of planned income. In either regard, startup companies should carefully design the part of the financial plan relating to sales growth. This should 
be based on publicly available data in order to convince VCs that startups are indeed capable of achieving targeted sales growth or capturing the targeted market share in the timeframe specified. Listing parties potentially interested in future acquisition of a startup can help indicate to VCs the potential exit possibilities, thus 'sweetening the deal'.

\section{Conclusions}

This article has examined differences in investment preferences across three distinct investment categories of Hungarian GVC investors in the pre-seed, seed, and expansion life-cycle stages by conducting three verbal protocol interviews in each resulting in 18 interviews in total. All investment managers evaluated two business plans from their portfolio consisting of the best and the worst. Each interview lasted for one hour and took place in undisturbed circumstances. Regarding selection of investment managers, a quota sampling method was used combined with reputation-based sampling to achieve maximum generalizability in each life-cycle stage. Through the use of verbal protocol analysis the actual investment screening procedure of the GVC in real-time could be captured. This eliminates recall bias associated with earlier post-hoc studies, which essentially based conclusions on VCs' potentially flawed recollection of their previous investment choices. Another issue related to such studies is that of post-hoc rationalization thereby causing individuals to produce reasons to justify their prior decisions. Although verbal protocol analysis has its own inherent limitations, most prominently in the relatively low number of verbal protocols that can be reasonably conducted, it is still widely used compared with conjoint analysis to examine $\mathrm{VC}$ investment decisions.

It was found that in overall terms GVCs mostly valued the financial indicators of the company. This was followed by the market and the product criteria in the seed and expansion stages. Generally in the literature, PVC investors value the market above financial indicators in direct contradiction to findings in this study. This is due to considerable state oversight placed on GVC investors required to follow statutory financial requirements when choosing investments. In the seed and expansion stages, the management team was not considered as an essential aspect of evaluations, but was more important than construction of the business plan. Management accorded a relatively low priority indicates resemblance to findings of previous real-time studies on PVC investment decisions (Hall \& Hofer, 1993; Zacharakis \& Meyer, 1995; Mason \& Stark, 2004). In the pre-seed stage, the situation is starkly different in that the most important aspects of examined startup companies were still the financial indicators closely followed by that of the management team. High importance of the management team can be attributed to a lack of operational history. Investment managers should therefore base decisions more on the capabilities of management rather than the business idea or financial data when a business plan is relatively short. Ultimately in the early stage, the management should convince the VC that they can fully realize potential of the startup venture. Essentially in this stage, the GVC also adopts some characteristics of angel investors particularly a preference for a credible management team (Hsu et al., 2014; Mason \& Stark, 2004), while maintaining the highest regard for financial indicators of the company, which is the most important quality that GVCs seek in every lifecycle stage. Quality of the business plan formed the least important quality in all three life-cycle stages, which is consistent with the value PVCs place on it (Hall \& Hofer, 1993; Zacharakis \& Meyer, 1995; Mason \& Stark, 2004). It was also found that GVCs place great emphasis on the innovational value of the product or service of the target company which is greatest in the pre-seed phase. This is consistent with the aims of the governmental program that contributed funds for GVCs to invest in.

This article has presented information on the investment preferences of governmental venture capital investment managers in three different life-cycle stage specialization categories. Startup companies seeking funding will moreover be able to locate information on what to do and what to avoid in formation of the business plan. The main limitation of this study lies in focus on the Hungarian venture capital market. Other researchers should be encouraged to also use verbal protocol analysis to examine governmental venture capitalists in their country of origin. This would assist in identifying geographical and temporal characteristics in a still a relatively underresearched field. Additional possible research questions may include addressing evaluation of pitch presentations by GVC investors, and the type of support entrepreneurs may expect from GVC investment other than financial support on the basis of metrics which GVC investors use to evaluate success of their investments.

\section{References}

Becsky-Nagy, P. \& Fazekas, B. (2015). Investment or Learning Curve? The effects of EU and government funds on the development of the Hungarian venture capital market. Public Finance Quarterly, 60(2), 243253.

Berlinger, E. (2019). How does the state destroy incentives in innovation financing? Economy and Finance: English-Language Edition of Gazdaság és Pénzügy, 6(3), 226-243. https://doi.org/10.33908\%2FEF.2019.3.1

Bruno, A.V. \& Tyebjee, T.T. (1983). The one that got away: A study of ventures rejected by capitalists. In J. A. Hornaday, J. A. Timmons \& K. H. Vesper (Eds.), Frontiers of Entrepreneurship Research. Proceedings of the 1983 Conference on Entrepreneurship, (pp. 289306). Wellesley, US: Babson College.

Chiu, I. \& Shu, L. H. (2010). Potential limitations of verbal protocols in design experiments. In ASME 2010. International Design Engineering Technical Conferences and Computers and Information in Engineering Conference, (pp. 287-296). Montreal, Canada: American Society of Mechanical Engineers. 
Cho, J. Y., \& Lee, E. (2014). Reducing Confusion about Grounded Theory and Qualitative Content Analysis: Similarities and Differences. The Qualitative Report, 19(32), 1-20. Retrieved from http://www.nova.edu/ ssss/QR/QR19/cho64.pdf

Colombo, M. G., Cumming, D. J. \& Vismara, S. (2016). Governmental venture capital for innovative young firms. The Journal of Technology Transfer, 41(1), 1024. https://doi.org/10.1007/s10961-014-9380-9

Czyżewska, M., Mroczek, T., Lewicki, A. \& Cwynar, A. (2016). The study of entrepreneurship growth drivers with the application of bayesian networks and global data. Humanitas University's Research Papers Management, 17(4), 129-146. https://doi.org/10.5604/18998658.1232692

Daszyńska-Żygadło, K., Słoński, T. \& Ligus, M. (2016). Investment in renewable energy technologies from the perspective of polish venture capital Funds. In: J. Krajíček, J. Nesleha, \& K. Urbanovsky (Eds.), European Financial Systems 2016. Proceedings of the $13^{\text {th }}$ International Scientific Conference, (pp. 79-85). Brno, Czech Republic: Masaryk University. Retrieved from https://is.muni.cz/do/econ/sborniky/2016/ EFS2016-Proceedings_final_September_19_final.pdf

Dávid, Sz. D., \& Becsky-Nagy, P. (2016). A kockázatitőkebefektetők kiválasztási kritériumai. Controller Info, 4(1), 22-29.

Dorsey, T. (1979). Operating Guidelines for Effective Venture Capital Funds Management. IC ${ }^{2}$ Institute, The University of Texas at Austin. Retrieved from http:// hdl.handle.net/2152/27758

Ericsson, K. A. \& Simon, H. A. (1993). Protocol analysis: Verbal reports as data. (Rev. ed.). Cambridge, US: The MIT Press.

Fazekas, B. (2018). Élet a piacon túl - Az állami hátterü kockázatitőke-finanszírozás elmélete és gyakorlata a magyarországi tapasztalatok tükrében (Doctoral dissertation). Debrecen, Hungary: Ihrig Károly Gazdálkodás- és Szervezéstudományok Doktori Iskola.

Fazekas, B. \& Becsky-Nagy, P. (2019). Mit jelez a tulajdonosi szerkezet? - A tulajdonosi szerkezet és a vállalkozások teljesítményének kapcsolata információs aszimmetriák mellett a magyarországi kockázatitőkebefektetések tükrében. Vezetéstudomány, 50(7-8), 3138.

https://doi.org/10.14267/VEZTUD.2019.07.03

Fazekas, B. \& Becsky-Nagy, P. (2020). Conceptualizing government venture capital agendas: The theoretical model of government backed venture capital funding. Under publication.

Hall, J. \& Hofer, C. W. (1993). Venture capitalists' decision criteria in new venture evaluation. Journal of Business Venturing, 8(1), 25-42. https://doi.org/10.1016/0883-9026(93)90009-T

Harrison, R. T., Mason, C. \& Smith, D. (2015). Heuristics, learning and the business angel investment decisionmaking process. Entrepreneurship \& Regional
Development, 27(9-10), 527-554.

https://doi.org/10.1080/08985626.2015.1066875

Horváth, D., \& Mitev, A. (2015). Alternativ kvalitatív kutatási kézikönyv. Budapest, Hungary: Aliena Kiadó. Hsu, D. K., Haynie, J. M., Simmons, S. A. \& McKelvie, A. (2014). What matters, matters differently: a conjoint analysis of the decision policies of angel and venture capital investors. Venture Capital, 16(1), $1-25$.

https://doi.org/10.1080/13691066.2013.825527

Invest Europe (2017). 2016 Private Equity Yearbook. Retrieved from https://www.investeurope.eu/ media/652475/yearbook-2016-europe-and-countryoverview-tables-member-version-20170510.xlsx

Invest Europe (2019). 2018 Central and Eastern Europe Private Equity Statistics. Retrieved from https://www. investeurope.eu/media/2630/ie_cee_report_2018 final.pdf

Jáki, E. \& Molnár, E. M. (2021). Venture capital and government involvement from a qualitative systematic literature review perspective. Acta Oeconomica, forthcoming.

Jáki, E. \& Molnár, E. M. (2017). Model of the State and EU Involvement in the Venture Capital Market. In Z. Zoltay-Paprika et al. (Eds.), ECMS 2017: 31st European Conference on Modelling and Simulation, (pp. 120-126). Nottingham, UK: European Council for Modelling and Simulation.

Jáki, E., Molnár, E. M. \& Walter, Gy. (2017). Government Sponsored Venture Capital: Blessing or Curse? Management (Slovenia), 12(4), 317-331. https://doi.org/10.26493/1854-4231.12.317-331

Kállay, L. \& Jáki, E. (2019). The impact of state intervention on the Hungarian venture capital market. Economic Research - Ekonomska Istraživanja, 33(1), 1-16. https://doi.org/10.1080/1331677X.2019.1629979

Karsai, J. (2017). Furcsa pár. Az állam szerepe a kockázatitőke-piacon Kelet-Európában. Budapest, Hungary: Közgazdasági Szemle Alapítvány - MTA Közgazdaság-és Regionális Tudományi Kutatóközpont - Közgazdaságtudományi Intézet.

Karsai, J. (2018). Government venture capital in central and eastern Europe. Venture Capital, 20(1), 73-102. https://doi.org/10.1080/13691066.2018.1411040

Karsai, J. (2019). Szakirodalmi áttekintés a korai fázisú, gyorsan növekvő innovativ vállalkozások tőkefinanszírozását segítö alternatív megoldásokról. Literature review on the alternative methods to enhance equity finance of early-stage high-growth innovative ventures. Budapest, Magyarország: Közgazdaság- és Regionális Tudományi Kutatóközpont Közgazdaságtudományi Intézet.

Khan, A. M. (1987). Assessing venture capital investments with noncompensatory behavioral decision models. Journal of Business Venturing, 2(3), 193-205. https://doi.org/10.1016/0883-9026(87)90008-5

Lovas, A. (2015). The Risk of Adverse Selection and its Management in the Process of Venture Capital Investment. Economy and Finance: English- 
Language Edition of Gazdaság és Pénzügy, 2(2), 186-202. http://unipub.lib.uni-corvinus.hu/2070/1/ EF2015v2n2p186eng.pdf

Lovas, A. \& Illés, R. (2018). A hazai kockázatitőkebefektetésekértékelése, különöstekintettelaJEREMIEalapok befektetéseire. Külgazdaság, 62(7-8), 30-55. http://real-j.mtak.hu/12768/4/2018_K\%C3\%BClg7-8. pdf\#page $=30$

Macmillan, I. C., Zemann, L. \& Subbanarasimha, P. N. (1987). Criteria distinguishing successful from unsuccessful ventures in the venture screening process. Journal of Business Venturing, 2(2), 123-137. https://doi.org/10.1016/0883-9026(87)90003-6

Mason, C. \& Stark, M. (2004). What do investors look for in a business plan? A comparison of the investment criteria of bankers, venture capitalists and business angels. International Small Business Journal, 22(3), 227-248

https://doi.org/10.1177/0266242604042377

Mason, C. \& Botelho, T. (2016). The role of the exit in the initial screening of investment opportunities: The case of business angel syndicate gatekeepers. International Small Business Journal, 34(2), 157-175. https://doi.org/10.1177/0266242614563419

Muzyka, D., Birley, S. \& Leleux, B. (1996). Tradeoffs in the investment decisons of European venture capitalists. Journal of Business Venturing, 11(4), 273287.

https://doi.org/10.1016/0883-9026(95)00126-3

Palyazat.gov.hu (2014): 2014-2020-as operatív programok társadalmi egyeztetése. Retrieved from https://www. palyazat.gov.hu/node/54899

Robinson, R. B. (1987). Emerging strategies in the venture capital industry. Journal of Business Venturing, 2(1), 53-77.

https://doi.org/10.1016/0883-9026(87)90019-X
Sandberg, W. R., \& Hofer, C. W. (1987). Improving new venture performance: The role of strategy, industry structure, and the entrepreneur. Journal of Business Venturing, 2(1), 5-28. https://doi.org/10.1016/0883-9026(87)90016-4

Sandberg, W. R., Schweiger, D. M. \& Hofer, C. W. (1988). The Use of Verbal Protocols in Determining Venture Capitalists' Decision Processes. Entrepreneurship Theory and Practice, 13(2), 8-20. https://doi.org/10.1177/104225878801300204

Shepherd, D. A. (1999). Venture Capitalists' Assessment of New Venture Survival. Management Science, 45(5), 621-632. https://doi.org/10.1287/mnsc.45.5.621

Smith, D., Harrison, R. T. \& Mason, C. (2010). Experience, heuristics and learning: the angel investment process. Frontiers of Entrepreneurship Research, 30(2). http:// digitalknowledge.babson.edu/fer/vol30/iss $2 / 3$

Tyebjee, T. T. \& Bruno, A. V. (1984). A Model of Venture Capitalist Investment Activity. Management Science, 30(9), 1051-1066. https://doi.org/10.1287/mnsc.30.9.1051

Zacharakis, A. L. \& Meyer, G. D. (1995). The venture capitalist decision: understanding process versus outcome. In W. D. Bygrave, B. J. Bird, S. Birley, N. C. Churchill, M. Hay, R. H. Keeley \& W. E. Wetzel Jr (Eds.), Frontiers of Entrepreneurship Research 1995, (pp. 465-478). Wellesley, US: Babson College.

Zacharakis, A. L. \& Meyer, G. D. (1998). A lack of insight: do venture capitalists really understand their own decision process? Journal of Business Venturing, 13(1), 57-76. https://doi.org/10.1016/S0883-9026(97)00004-9

Zacharakis, A. L. \& Shepherd, D. A. (2005). A nonadditive decision-aid for venture capitalists' investment decisions. European Journal of Operational Research, 162(3), 673-689.

https://doi.org/10.1016/j.ejor.2003.10.028 